\title{
Malondialdehyde and Antioxidant Enzymes in Maternal and Cord Blood, and their Correlation in Normotensive and Preeclamptic Women
}

\author{
Mohd Suhail $^{\mathrm{a}, \mathrm{b}, \mathrm{e}}$, Safia Suhail ${ }^{\mathrm{b}}$, Bharat Kumar Gupta ${ }^{\mathrm{c}}$, Vinay Bharat ${ }^{\mathrm{d}}$
}

\begin{abstract}
Background: An increased oxidative level and decreased antioxidant activities in the blood of preeclamptic women have been reported by us and other workers. The present study was aimed to evaluate oxidative stress in infants born to preeclamptic mothers, and to examine whether cord blood with oxygen radical disease had different total enzymatic antioxidant status than those without preeclampsia.
\end{abstract}

Methods: The present study consisted of 23 normotensive (served as control) and 23 preeclamptic mothers. We compared their oxidative and anti-oxidative system in maternal and cord blood of pair-matched mother and neonate. Their blood malondialdehyde (MDA), antioxidant enzymes were determined and compared to evaluate if pro-oxidative status of preeclampsia differs from the status in cord blood of pair-matched neonate.

Results: The MDA content in preeclamptic maternal plasma was significantly high $(\mathrm{p}<0.001)$ compared to that of control. Interestingly, its content in preeclamptic cord blood was significantly low $(\mathrm{p}<0.001)$ compared to their pair-matched maternal blood. Superoxide dismutase (SOD) activity was $8.7 \%$ higher in cord as compared to pair-matched normotensive maternal blood which was significant $(\mathrm{p}=0.01)$ whereas in preeclamptic cord the level decreased significantly $(\mathrm{p}=0.011)$ in comparison to pair-matched preeclamptic maternal. Glutathione peroxidase (GPx) was $16.4 \%$

Manuscript accepted for publication July 24, 2009

aDepartment of Biochemistry, University of Allahabad, Alla habad-211002, India.

${ }^{\mathrm{b}}$ City Nursing \& Maternity Home Research Center, 21, Minhajpur, Al lahabad-211003, India.

'Department of Biochemistry \& Immunology, Subharti Medical Col lege, S. V. S. University, Meerut- 250005, India

${ }^{\mathrm{d} D e p a r t m e n t}$ of Pathology, Subharti Medical College, S. V. S. Univer sity, Meerut- 250005, India

${ }^{\mathrm{e}}$ Corresponding author: City Nursing \& Maternity Home Research

Center, 21, Minhajpur-211003, India. E-mail: profmsuhail@gmail.com

doi:10.4021/jocmr2009.07.1252 higher in normotensive cord compared to maternal blood, and $7 \%$ low in preeclamptic cord compared to pair-matched maternal blood. The increase was significant $(\mathrm{P}=0.011)$ in normotensive cord whereas in preeclamptic cord the decrease was insignificant $(\mathrm{p}=0.06)$. Contrary to earlier reports on catalase activity, our results showed $20.97 \%$ elevation in normotensive and $16.12 \%$ increase in the preeclamptic cord blood compared to their pair-matched maternal blood. This change was significant with $\mathrm{p}=0.01$ and $\mathrm{p}=0.017$ in control and preeclamptic group respectively.

Conclusions: Our results showed the significantly low MDA contents in the pair-matched cord blood and the activities of SOD, GPx and Catalase mentioned above, we conclude that the oxidative stress status is low in the blood of neonates born to preeclamptic mothers. Further studies are needed to explore strategies so that the normal levels of antioxidant vitamins are maintained to combat preeclampsia in women at high risk.

Keywords: Maternal; Cord blood; Malondialdehyde; Antioxidant enzymes; Glutathione peroxidase; Glutathione reductase; Superoxide dismutase; Catalase

\section{Introduction}

Cord blood antioxidant capacity is the result of overall intrauterine experience, making the intrauterine period crucial of the fetal development, which is the result of complex interaction among the three components of maternal-placental-fetal unit. Babies born at term to preeclamptic mothers provide a unique opportunity to have an insight into the mechanism and implications of the fetal development, secondary to intrauterine redox-status.

Our aim was to assess the relationship between lipid peroxidation and maternal/cord blood enzymatic antioxidant capacity and to examine whether cord blood with oxygen radical disease had different total enzymatic antioxidant status than those without preeclampsia (PE), a disorder of pregnancy characterized by pregnancy-induced hypertension $(\geq 140 \mathrm{mmHg}$ systolic and/or $\geq 90 \mathrm{mmHg}$ diastolic blood pressure), new-onset proteinuria ( $\geq 300 \mathrm{mg}$ protein/day), and 
edema occurring in the second half of pregnancy.

Oxidative stress has been implicated in the pathophysiology of PE because it damages the maternal vascular endothelium, and there is indisputable evidence that the normal role of this cell layer is severely compromised in PE [1]. With cumulative evidences in recent years, we have recently shown that a biochemical imbalance in preeclampsia occurs with an increase of oxidative stress and lipoperoxidation and, at the same time, a deficient antioxidant protection $[2,3,4]$.

Significant elevation of malondialdehyde (MDA) levels in cord blood of pair-matched preeclamptic mother have been reported $[5,6]$ whereas others have concluded decline in its level [7] or no significant change [8, 9], but Karabulut et al [10] inferred elevation of MDA levels both in cord and mother during preeclamptic development compared to normal pregnancy. Similarly, contradictions exist about the level of antioxidant enzymes in the cord blood of preeclamptic mothers.

Significantly decreased enzymatic activities of superoxide dismutase (SOD), glutathione peroxidase (GPx), and catalase (CAT) have been reported $[6,7,11,12]$ in cord blood of the full term newborns of preeclamptic mothers as compared to their pair-matched maternal blood. Contrary findings of increased SOD activity [8] and no change in the activity of GPx in the cord blood have also been reported $[8,9]$.

Inconsistency in these reports has led us to take up the present study to assess the relationship between lipoperoxidation and pair-matched cord blood antioxidant enzymatic activities; and to examine whether the maternal and cord plasma concentrations of MDA and these enzymes levels differ between preeclamptic and healthy pregnant women. Further, we aimed to investigate whether a variation or correlation in oxidant and antioxidant levels between maternal blood and fetal cord blood exists consequent to their antioxidant enzymes activities.

\section{Materials and Methods}

\section{Chemicals}

NADPH, Oxidized glutathione (GSSG), Glutathione Reductase (GRx), EDTA, Thiobarbituric acid (TBA) and butylated hydroxytoluene (BHT) were from Sigma Chemical Company (St. Louis, MO, USA). Other chemicals of analytical grade were obtained from either E. Merck (Mumbai, India), BDH or SISCO Chemicals (Mumbai, India).

\section{Subjects}

In India, pregnant women are encouraged to book and to attend regular antenatal check ups. Standard antenatal care is defined as monthly visits up to 28 weeks; fortnightly un- til 34 weeks, and weekly visits thereafter. The present study was carried out with the prior approval of local ethical committee. The patients in our study included normal pregnant women with normal blood pressure, and preeclamptic women admitted to our hospital who had been or not under regular care and also those who were referred from private sectors or primary health centers. Twenty three normal pregnant women who served as control, and 23 severely preeclamptic patients with singleton pregnancies were selected.

Control group had two and preeclamptic group had five caesarian sections, because of prolonged labor. They gave their consent in writing and the objectives of the study were fully explained to them in detail prior to taking consent. Height and weight of the subjects were measured to calculate their body mass index (BMI). Clinical examination and history taking excluded women addicted to tobacco, patients with diabetes, ischemic heart disease, a history of stroke, kidney disorders or other conditions of known free radical etiology. The criteria for dividing women into normal and severely preeclamptic groups were set at a blood pressure of $\geq 160 / 110 \mathrm{mmHg}$ with proteinuria, over $0.3 \mathrm{~g}$ protein/day, and edema.

\section{Sample Collection}

Blood samples were collected from the mothers at delivery, cord blood was obtained immediately post partum from the umbilical vein after clamping of the cord by labor ward staff. In each case, $10 \mathrm{ml}$ blood were drawn into a sodium heparin vacutainer tube for separating plasma and stored at $4{ }^{\circ} \mathrm{C}$ until processed. Maternal and umbilical cord blood samples were handled identically; all samples were processed within 20 hours of sampling.

The blood samples were centrifuged at $1000 \mathrm{~g}$ for 15 min at $4{ }^{\circ} \mathrm{C}$, the isolated red cells were washed $4-5$ times with $0.154 \mathrm{M} \mathrm{NaCl}$ to remove plasma and buffy coat. After the final wash, required packed red cells were lysed by hypotonic shock and different dilutions were used as hemolysates.

\section{Estimation of lipid peroxidation}

Lipid peroxidation was quantified following the method of Jain et al [13]. Packed red cells $(0.2 \mathrm{ml})$ were used for the quantification of malondialdehyde (MDA) as thiobarbituric acid reactive substances (TBARS). Aliquots of $0.2 \mathrm{ml}$ were mixed thoroughly with $0.8 \mathrm{ml}$ of phosphate-buffered saline (8.1 g NaCl, $2.302 \mathrm{~g} \mathrm{Na}_{2} \mathrm{HPO}_{4}$, and $0.194 \mathrm{~g} \mathrm{NaH}_{2} \mathrm{PO}_{4} / \mathrm{L}, \mathrm{pH}$ 7.4) and $25 \mu \mathrm{l}$ of butylatedhydroxytoulene (BHT, $88 \mathrm{mg} / 10$ $\mathrm{ml}$ absolute alcohol) solution. After adding $0.5 \mathrm{ml}$ of $30 \%$ trichloroacetic acid, the samples were vortexed and allowed to stand in ice for at least $2 \mathrm{hrs}$, and then centrifuged at 2000 $\mathrm{g}$ at $25^{\circ} \mathrm{C}$ for $15 \mathrm{~min}$. One $\mathrm{ml}$ of supernatant was mixed with $75 \mu \mathrm{l}$ of $0.1 \mathrm{M}$ EDTA and $250 \mu \mathrm{l}$ of $1 \%$ thiobarbituric acid in $0.05 \mathrm{M} \mathrm{NaOH}$ and placed on boiling water for $15 \mathrm{~min}$. After 
cooling to room temperature, absorbance was measured at $532 \mathrm{~nm}$ and $600 \mathrm{~nm}$. Absorbance at $600 \mathrm{~nm}$ was subtracted from absorbance at $532 \mathrm{~nm}$ for evaluation of MDA. BHT, an antioxidant, was added to prevent MDA formation during assay, which could result in falsely elevated TBA reactivity. The addition of BHT to standard MDA did not affect the color development with TBA. MDA contents were expressed as $\mathrm{nmol} / \mathrm{gHb}$.

\section{Assay of GPx (EC 1.11.1.9) activity}

GPx activity was measured spectrophotometrically following the method of Paglia and Valentine [14]. The lysate was mixed with an equal volume of Drabkin's reagent to convert all hemoglobin to the stable cyanmethemoglobin form. Exactly $0.1 \mathrm{ml}$ of this mixture was added to $2.58 \mathrm{ml}$, $50 \mathrm{mM}$ phosphate, $\mathrm{pH} 7.0$ containing $5 \mathrm{mM}$ EDTA. The following solutions were then added in turn: $100 \mu \mathrm{l}, 8.4 \mathrm{mM}$ NADPH, $10 \mu \mathrm{l} \mathrm{GRx}(0.3 \mathrm{U} / \mathrm{ml}), 10 \mu \mathrm{l}, 1.125 \mathrm{M}$ sodium azide and $100 \mu \mathrm{l}, 150 \mathrm{mM}$ GSH. The reaction mixture was allowed to equilibrate at $20 \mathrm{oC}$ in the cuvette of the spectrophotometer. The enzymatic reaction was initiated by addition of 100 $\mu 1,2.2 \mathrm{mM} \mathrm{H}_{2} \mathrm{O}_{2}$. The conversion of NADPH to NADP was followed by continuous monitoring of the change in absorbance of the system at $340 \mathrm{~nm}$ between 2 and 4 minutes after initiation of the reaction. One unit of GPx was considered to be the amount necessary to oxidize $1 \mu \mathrm{mol} \mathrm{NADPH} / \mathrm{min}$. Activity is expressed as $\mathrm{U} / \mathrm{gHb}$.

\section{Assay of SOD (EC 1.15.1.1) activity}

SOD activity was measured according to the method of Beutler [15]. Briefly, the reaction is dependent on the presence of superoxide anions that cause the oxidation of pyrogallol SOD which inhibits the auto-oxidation of pyrogallol, by catalyzing the breakdown of superoxide. The inhibition of pyrogallol oxidation by SOD was monitored and the amount of enzyme producing 50\% inhibition was defined as one unit of enzyme activity. The assay mixture contained $1 \mathrm{M}$ Tris HCl-5 mM EDTA buffer, pH 8.0, and $10 \mathrm{mM}$ pyrogallol. The inhibition of pyrogallol oxidation by SOD was monitored at $420 \mathrm{~nm}$ on a recorder giving full-scale reading of $1 \mathrm{OD}$, the activity of enzyme was evaluated and expressed as $\mathrm{U} / \mathrm{gHb}$.

\section{Assay of Catalase (EC 1.11.1.6) activity}

Catalase decomposes the $\mathrm{H}_{2} \mathrm{O}_{2}$ and forms water and molecular oxygen. $\mathrm{H}_{2} \mathrm{O}_{2}$ absorbs maximum light at $240 \mathrm{~nm}$. When $\mathrm{H}_{2} \mathrm{O}_{2}$ is decomposed by catalase, the absorbance decreases. Determination of catalase activity was assayed by monitoring the rate of decomposition of $\mathrm{H}_{2} \mathrm{O}_{2}$ spectrophotometrically at $240 \mathrm{~nm}$ following the procedure of Aebi [16]. The assay mixture contained $2.0 \mathrm{ml}$ of enzyme or homolysate and $1 \mathrm{ml}, 30 \mathrm{mM} \mathrm{H}_{2} \mathrm{O}_{2}$ at $20{ }^{\circ} \mathrm{C}$ with the final volume of $3.0 \mathrm{ml}$ against a blank containing $1 \mathrm{ml}, 50 \mathrm{mM}$ phosphate buffer, $\mathrm{pH} 7.0$, instead of substrate and $2 \mathrm{ml}$ enzyme solution or hemolysate. The reaction was started by the addition of $\mathrm{H}_{2} \mathrm{O}_{2}, 0.9 \mathrm{ml}$ of $1 \mathrm{M}$ Tris, $5 \mathrm{mM}$ EDTA buffer, $\mathrm{pH} 7.0$ and $0.1 \mathrm{ml}$ of the sample. The decrease in absorbance was measured with a recorder at an interval of 30 seconds for 3 minutes. The value of absorbance of the reference was subtracted from that of the test cuvette before units of activity

Table 1. Demographic and clinical characteristics of normotensive (control) and severe preeclamptic subjects

\begin{tabular}{llll}
\hline Parameters & Normotensive & Severely & P*-value \\
& control group & preeclamptic group & \\
\hline Number of maternal/neonatal pairs & 23 & 23 & 0.275 \\
Maternal age (years) & $29.1 \pm 6.9$ & $26.8 \pm 7.2$ & 0.376 \\
BMI at delivery $\left(\mathrm{kg} / \mathrm{m}^{2}\right)$ & $22.1 \pm 2.5$ & $21.4 \pm 2.8$ & 0.221 \\
Gestational age (weeks) & $33.8 \pm 3.9$ & $32.2 \pm 4.8$ & $<0.0001$ \\
BP at delivery, systolic $(\mathrm{mm} / \mathrm{Hg})$ & $109.8 \pm 12.9$ & $164.5 \pm 13.6$ & $<0.0001$ \\
BP at delivery, diastolic $(\mathrm{mm} / \mathrm{Hg})$ & $65.6 \pm 11.4$ & $111.4 \pm 14.2$ & 0.324 \\
Pulse rate (beats/min) & $71.4 \pm 1.6$ & $70.8 \pm 2.4$ & $/$ \\
Proteinuria (g/day) & Nil & $1.24 \pm 0.86$ & $/$ \\
Edema & Nil & ++ in all cases & \\
\hline
\end{tabular}

Values are expressed as mean $\pm \mathrm{SD}$; BMI- body mass index; $\mathrm{BP}$ - blood pressure, $\mathrm{P}^{*}=$ Two-Samples t-test probability 
Table 2. Concentrations of malondialdehyde and activities of various antioxidant enzymes in pair-matched normotensive (control) and severely preeclamptic maternal and cord blood

\begin{tabular}{|c|c|c|c|c|}
\hline Parameters & $\begin{array}{l}\text { Normotensive maternal } \\
(\mathrm{n}=\mathbf{2 3})\end{array}$ & $\begin{array}{l}\text { Normotensive cord } \\
(\mathrm{n}=\mathbf{2 3})\end{array}$ & $\begin{array}{l}\text { Preeclamptic maternal } \\
(\mathrm{n}=23)\end{array}$ & $\begin{array}{l}\text { Preeclamptic cord } \\
(n=23)\end{array}$ \\
\hline $\begin{array}{l}\text { Malondialdehyde (MDA) } \\
(\mathrm{nmol} / \mathrm{gHb})\end{array}$ & $\begin{array}{l}9.02 \pm 2.36 \\
\left(\mathrm{Cl}^{*}: 8.008 \text { to } 10.04\right)\end{array}$ & $\begin{array}{l}7.36 \pm 1.62 \\
\left(\mathrm{Cl}^{*}: 6.66 \text { to } 8.06\right)\end{array}$ & $\begin{array}{l}11.98 \pm 1.83 \\
\left(\mathrm{Cl}^{*}: 11.19 \text { to } 12.77\right)\end{array}$ & $\begin{array}{l}8.02 \pm 1.05 \\
\left(\mathrm{Cl}^{*}: 7.56 \text { to } 8.47\right)\end{array}$ \\
\hline $\begin{array}{l}\text { Superoxide dismutase } \\
(\mathrm{U} / \mathrm{gHb})\end{array}$ & $\begin{array}{l}1135.95 \pm 100.28 \\
\left(\mathrm{Cl}^{*}: 1092.58 \text { to } 1179.32\right)\end{array}$ & $\begin{array}{l}1235.17 \pm 119.07 \\
\left(\mathrm{Cl}^{*}: 1183.68 \text { to } 1286.66\right)\end{array}$ & $\begin{array}{l}921.92 \pm 117.54 \\
\left(\mathrm{Cl}^{*}: 871.09 \text { to } 972.74\right)\end{array}$ & $\begin{array}{l}842.16 \pm 81.24 \\
\left(\mathrm{Cl}^{*}: 807.03 \text { to } 877.29\right)\end{array}$ \\
\hline $\begin{array}{l}\text { Glutathione peroxidase } \\
(\mathrm{U} / \mathrm{gHb})\end{array}$ & $\begin{array}{l}15.21 \pm 3.04 \\
\left(\mathrm{Cl}^{*}: 13.9 \text { to } 16.53\right)\end{array}$ & $\begin{array}{l}17.71 \pm 2.27 \\
\left(\mathrm{Cl}^{*}: 16.73 \text { to } 18.69\right)\end{array}$ & $\begin{array}{l}13.92 \pm 1.36 \\
\left(\mathrm{Cl}^{*}: 13.33 \text { to } 14.51\right)\end{array}$ & $\begin{array}{l}12.95 \pm 1.89 \\
\left(\mathrm{Cl}^{*}: 12.14 \text { to } 13.77\right)\end{array}$ \\
\hline $\begin{array}{l}\text { Glutathione reductase } \\
(\mathrm{U} / \mathrm{gHb})\end{array}$ & $\begin{array}{l}11.24 \pm 3.03 \\
\left(\mathrm{Cl}^{*}: 9.93 \text { to } 12.54\right)\end{array}$ & $\begin{array}{l}10.98 \pm 2.90 \\
\left(\mathrm{Cl}^{*}: 9.97 \text { to } 12.23\right)\end{array}$ & $\begin{array}{l}8.98 \pm 2.44 \\
\left(\mathrm{Cl}^{*}: 7.93 \text { to } 10.04\right)\end{array}$ & $\begin{array}{l}8.85 \pm 2.46 \\
\left(\mathrm{Cl}^{*}: 7.79 \text { to } 9.92\right)\end{array}$ \\
\hline Catalase (kU/gHb) & $\begin{array}{l}98.21 \pm 21.17 \\
\left(\mathrm{Cl}^{*}: 89.05 \text { to } 107.36\right)\end{array}$ & $\begin{array}{l}118.80 \pm 25.81 \\
\left(\mathrm{Cl}^{*}: 107.64 \text { to } 129.96\right)\end{array}$ & $\begin{array}{l}124.70 \pm 17.48 \\
\left(\mathrm{Cl}^{*}: 117.14 \text { to } 132.26\right)\end{array}$ & $\begin{array}{l}144.8 \pm 34.99 \\
\left(\mathrm{Cl}^{*}: 129.67 \text { to } 159.93\right)\end{array}$ \\
\hline
\end{tabular}

Values are expressed as mean $\pm \mathrm{SD} ; \mathrm{Cl}^{*}=95 \%$ Confidence Interval for mean

were calculated. The activity of catalase was evaluated and expressed as $\mathrm{kU} / \mathrm{gHb}$.

\section{Assay of GRx (EC 1.8.1.7) activity}

The main reagent was prepared by combining $18 \mathrm{ml}$ of $\mathrm{KH}_{2} \mathrm{PO}_{4}$ buffer $139 \mathrm{mM}, 0.76 \mathrm{mM}$ EDTA, $\mathrm{pH} 7.4$, and $2 \mathrm{ml}$ of $2.5 \mathrm{mM}$ NADPH. The sample (20 $\mu \mathrm{l}$ of 1: 20 hemolysate $+20 \mu \mathrm{L}$ of $\mathrm{KH}_{2} \mathrm{PO}_{4}$ buffer), $220 \mu \mathrm{l}$ of the main reagent and 5 $\mu$ of FAD $0.315 \mathrm{mM}+10 \mu$ of $\mathrm{KH}_{2} \mathrm{PO}_{4}$ buffer were added to the cuvette and the absorbance at $340 \mathrm{~nm}$ was monitored for 200s (step A). Then $30 \mu \mathrm{l}$ of GSSG $22 \mathrm{mM}+10 \mu \mathrm{l}$ of $\mathrm{KH}_{2} \mathrm{PO}_{4}$ buffer were added to start the reaction and the absorbance was followed for $175 \mathrm{~s}$ (step B). The final reaction volume was $315 \mu \mathrm{l}$. The difference in absorbance per minute between steps $\mathrm{B}$ and $\mathrm{A}$ was used to calculate the enzyme activity. The unit is $\mu \mathrm{mol}$ of NADPH oxidized /min and the GRx activity is evaluated and expressed as $\mathrm{U} / \mathrm{gHb}$ [17].

\section{Hemoglobin estimation}

The method of Tentori and Salvati [18] was employed for hemoglobin estimation. Hemoglobin content of the sample was measured using cyanmethemoglobin method by mixing $20 \mu \mathrm{l}$ of blood and $5 \mathrm{ml}$ of (1:251 diluted) ferricyanide reagent, $\mathrm{K}_{3} \mathrm{Fe}(\mathrm{CN})_{6}, 200 \mathrm{mg} ; \mathrm{KCN} 50 \mathrm{mg} ; \mathrm{K}_{2} \mathrm{HPO}_{4} 140$ $\mathrm{mg}$; appropriate amount of detergent Triton X-100 dissolved

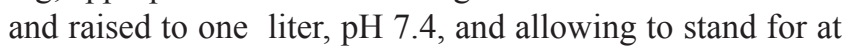
least $3 \mathrm{~min}$. Afterwards, absorbance was read at $540 \mathrm{~nm}$ using water as blank.

\section{Statistical analysis}

SPSS version 15.0 for Windows (SPSS Inc., Chicago, IL, USA) software package was used to analyze the data and to obtain the box-plots for various parameters. The results were statistically analyzed using paired-samples t-test to compare both maternal/cord blood of normotensive pregnant and preeclamptic patients groups. The t-test statistical significance was set at $\mathrm{P} \leq 0.05$. Values were expressed as Mean \pm Standard Deviation.

\section{Results}

We evaluated the quantum of enzymatic antioxidant defense in maternal and cord blood of two groups of pairmatched maternal and neonates. Control group consisted of 23 uncomplicated, normotensive-pregnancies and the second group included 23 severely preeclamptic patients, all singleton pregnancies. Control group had two, whereas preeclamptic group had four caesarian sections, because of prolonged labor. The clinical characteristics of these groups are shown in Table 1. The activities of SOD, GPx, GRx and Catalase are summarized as mean \pm standard deviation in Table 2.

The MDA contents varied from 4.12 to $12.79 \mathrm{nmol} /$ $\mathrm{gHb}$ in normotensive maternal and 3.89 to $11.06 \mathrm{nmol} / \mathrm{gHb}$ in normotensive cord, whereas it varied from 8.75 to 15.19 $\mathrm{nmol} / \mathrm{gHb}$ in preeclamptic maternal and 6.75 to $10.34 \mathrm{nmol} /$ $\mathrm{gHb}$ in preeclamptic cord. Their mean values are mentioned in Table 2. The MDA content in preeclamptic maternal blood was found to be $32.8 \%$ higher than that of control. There was 


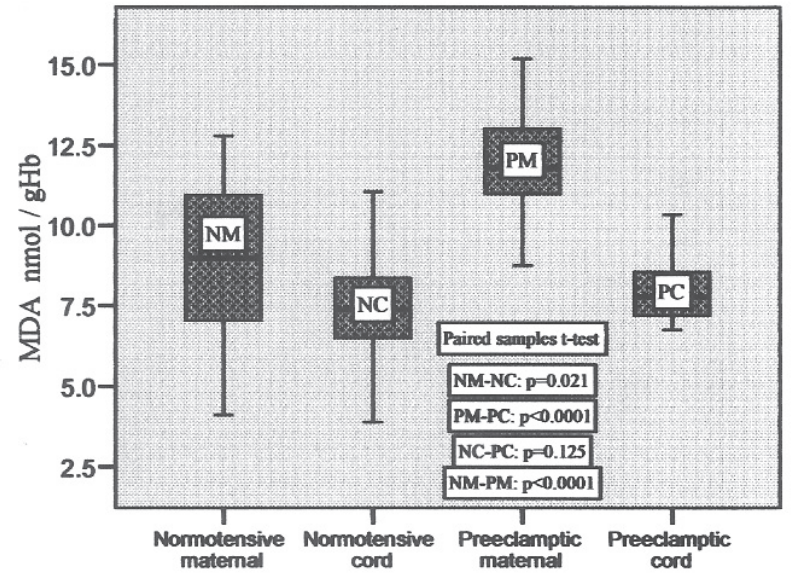

Figure 1. MDA concentrations in pair-matched normotensive and preeclamptic maternal and cord blood.

no significant difference $(\mathrm{p}=0.021)$ between control maternal and cord blood levels. The MDA content in preeclamptic maternal plasma was significantly high $(\mathrm{p}<0.001)$ compared to that of control. However, its content in preeclamptic cord blood compared to their pair-matched maternal blood was significantly low $(\mathrm{p}<0.001)$. The variations in its contents in pair-matched normotensive and preeclamptic maternal as well as cord blood have been shown in Figure 1.

The activity of superoxide dismutase ranged from 980.73 to $1375.65 \mathrm{U} / \mathrm{gHb}, 1055.59$ to $1465.97 \mathrm{U} / \mathrm{gHb}, 702.05$ to $1141.71 \mathrm{U} / \mathrm{gHb}$ and 655.69 to $970.12 \mathrm{U} / \mathrm{gHb}$ in normotensive maternal, pair-matched cord, preeclamptic maternal and pair-matched cord, respectively, with the mean values given in Table 2. It was found to be $8.7 \%$ higher in cord as compared to pair-matched normotensive maternal blood which was significant $(\mathrm{p}=0.01)$, whereas in preeclamptic cord the level decreased significantly $(\mathrm{p}=0.011)$ in comparison to pair-matched preeclamptic maternal. The variations in its

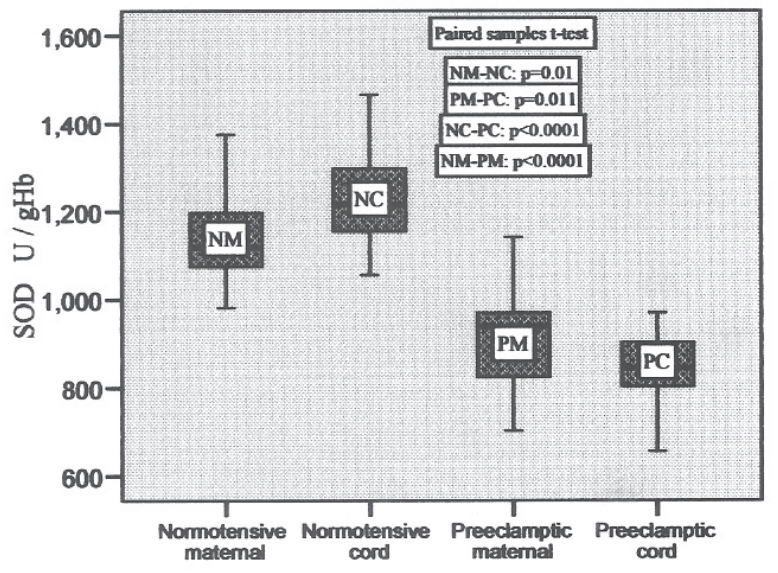

Figure 2. SOD activities in pair-matched normotensive and preeclamptic maternal and cord blood.

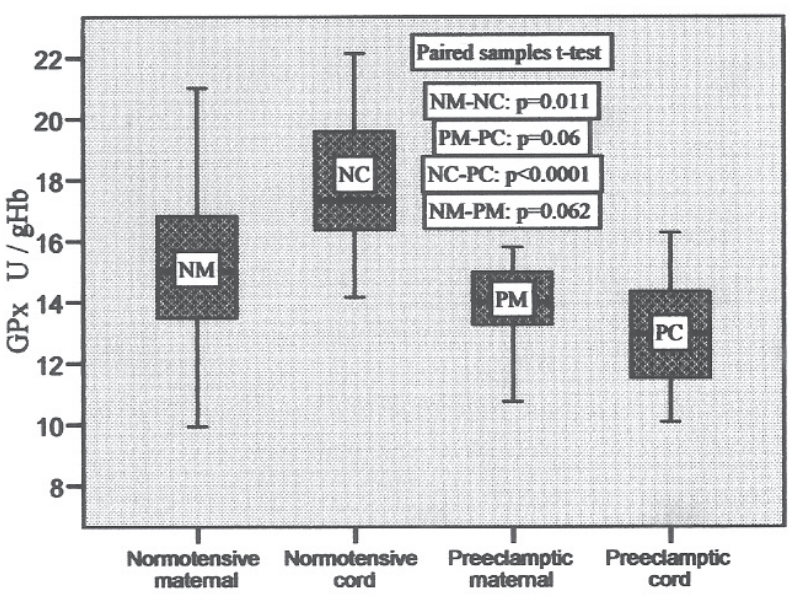

Figure 3. GPx activities in pair-matched normotensive and preeclamptic maternal and cord blood.

levels in pair-matched normotensive and preeclamptic maternal as well as cord blood are shown in Figure 2.

Glutathione peroxidase (GPx) was found to vary from 9.94 to $21.02 \mathrm{U} / \mathrm{gHb}, 14.15$ to $22.14 \mathrm{U} / \mathrm{gHb}, 10.75$ to 15.80 $\mathrm{U} / \mathrm{gHb}, 10.08$ to $16.28 \mathrm{U} / \mathrm{gHb}$ in normotensive maternal, pair-matched cord, preeclamptic maternal, pair-matched cord, respectively, with their mean values mentioned in Table 2 . It was $16.4 \%$ higher in normotensive cord compared to maternal blood and 7\% low in preeclamptic cord compared to pair-matched maternal blood. The increase was significant $(\mathrm{P}=0.011)$ in normotensive cord, whereas in preeclamptic cord the decrease was insignificant $(\mathrm{p}=0.06)$. The variations in activities in pair-matched normotensive and preeclamptic maternal as well as cord plasma are shown in Figure 3.

In control group, the glutathione reductase (GRx) activity ranged from 5.84 to $17.28 \mathrm{U} / \mathrm{gHb}$ in maternal blood and 4.24 to $14.89 \mathrm{U} / \mathrm{gHb}$ in cord blood, whereas in preeclamptic group it varied from 4.55 to $12.18 \mathrm{U} / \mathrm{gHb}$ in maternal and

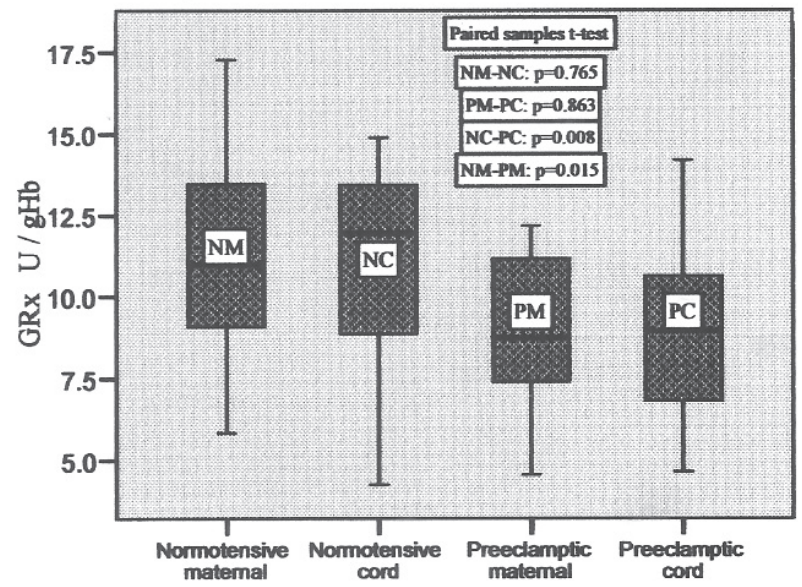

Figure 4. GRx activities in pair-matched normotensive and preeclamptic maternal and cord blood. 


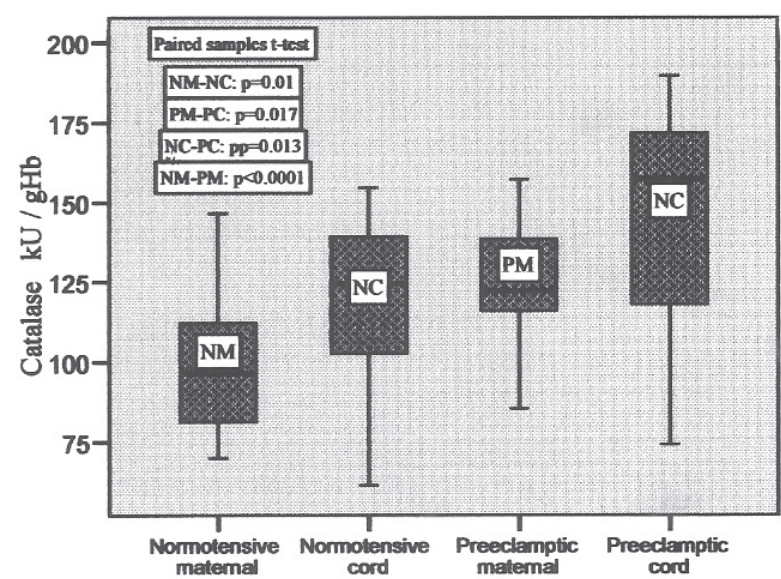

Figure 5. Catalase activities in pair-matched normotensive and preeclamptic maternal and cord blood.

4.65 to 14.20 in cord blood with the mean values shown in Table 2. The box-plots of these values are shown in Figure 4, which represent these variations clearly with no significant difference between maternal and pair-matched cord blood in control $(p=0.765)$, and preeclamptic group $(p=0.863)$. But, the difference in the mean values of maternal and cord blood of both groups was significant $(\mathrm{p}=0.015$ and $\mathrm{p}=0.008$, respectively). There was $20.1 \%$ decrease in preeclamptic maternal blood and $19.4 \%$ decrease in the GRx activity in preeclamptic cord blood when compared to their respective normotensive maternal and cord blood.

Catalase activity was found elevated in the cord blood of both the groups. There was $20.97 \%$ elevation in normotensive and $16.12 \%$ increase in the preeclamptic cord blood compared to their pair-matched maternal blood. This change was significant with $p=0.01$ and $p=0.017$ in control and preeclamptic group respectively. These changes are represented in the form of box plots in Figure 5. The activity ranged from 69.99 to $146.54,61.43$ to $154.73,85.46$ to 157.23 and 74.25 to 189.58 in normotensive maternal, cord, preeclamptic maternal and cord blood, respectively, with the mean values shown in Table 2 .

\section{Discussion}

The present study investigated maternal plasma enzymatic antioxidant levels during normal and complicated preeclamptic pregnancies and their relationships with neonatal antioxidant levels. Cumulative evidences in recent years show that a biochemical imbalance in preeclampsia occurs with an increase of oxidative stress and a deficient antioxidant protection $[2,3,4]$. Indeed, free radicals released from the poorly perfused fetoplacental unit initiate lipid peroxidation by attacking polyunsaturated fatty acids in cell membranes, converting them to lipid peroxides and to a variety of secondary metabolites. Uncontrolled peroxidation alters membrane fluidity and permeability, therefore the lipid peroxides and their secondary metabolites, such as malondialdehyde (MDA, a good indicator of oxidant forces formed at a primary site), are then transported through the circulation by lipoproteins, causing damage at distant tissues.

In the preeclamptic pregnancy, the oxidant/antioxidant balance of normal pregnancy is skewed to favor oxidants at the expense of antioxidants. Antioxidant defense systems include the chain-breaking antioxidants, such as vitamin $\mathrm{C}$ and vitamin $\mathrm{E}$, and the antioxidant enzymes. Lipid-phase chainbreaking antioxidants, the most important of which is probably vitamin E [19], scavenge radicals in membranes and lipoprotein particles and are central to the prevention of lipid peroxidation. Aqueous-phase chain-breaking antioxidants directly scavenge radicals present in the aqueous compartment. Vitamin C or ascorbate is the most important aqueous phase chain-breaking antioxidant [20]. It is well established that there is synergy between vitamins $\mathrm{C}$ and $\mathrm{E}$. This interaction between vitamin $\mathrm{C}$ and vitamin $\mathrm{E}$ has been confirmed in vivo by workers [21], who have reported that supplementation of healthy adults with ascorbic acid increases ascorbic acid and lipid-standardized alpha-tocopherol levels in plasma, and that supplementation with alpha-tocopherol is associated with increased plasma ascorbic acid concentration, as well as improved vitamin E status. Our recent reports [22] showed significantly high vitamin $\mathrm{C}$ levels in the cords of both normotensive as well as preeclamptic mothers, which showed retention of comparatively elevated antioxidant capacity in the cords.

Our results showed $32.8 \%$ higher MDA contents in preeclamptics compared to normotensive maternal plasma. Earlier, it has been reported [23] that preeclamptic placenta contains higher MDA than those from normal pregnancies. Our previous reports $[3,4]$ have shown significant elevation of MDA or TBARS during the development of PE. This may result in a greater potential for endothelial damage ultimately leading to enhanced diastolic pressure [20] which further aggravates the condition of preeclamptic patients. Enhanced ROS in turn can oxidize many other important biomolecules including erythrocyte membrane phospholipids. The interesting finding of the present study is $33.1 \%$ lower level of MDA concentrations in the cord plasma as compared to maternal plasma in preeclamptics. Our present findings on MDA concentrations are consistent with those of Orhan et al [7].

Superpxode dismutase (SOD), Catalase, GRx, and glutathione peroxidase (GPx) are important parts of the defense system. SOD protects and revitalizes cells and reduces the rate of cell destruction. It neutralizes some of the most dangerous free radicals, the superoxide radicals, before they can wreak havoc on the body. Superoxide generation also perpetuates oxidative stress and lipid peroxidation through the oxidation of mitochondrial iron-sulphur clusters such as aconi- 
tase, which subsequently stimulate membrane phopholipid peroxidation by alkoxyl radicals [24]. SOD is an important antioxidant enzyme having an antitoxic effect against super oxide anion and catalyses the reaction in which superoxide radicals are converted to $\mathrm{H}_{2} \mathrm{O}_{2}$ and $\mathrm{O}_{2}$. It decreases superoxide anion concentration in the vascular cell [25], a mechanism that could counteract the development of hypertension. In normotensive cord, SOD increased $8.7 \%$ compared to maternal blood, but in preeclamptic cord it decreased to $8.65 \%$ as compared to their pair-matched maternal blood, and both the alterations were significant, $p=0.01$ and $p=$ 0.011 , respectively. Our results pertaining to SOD activity in preeclamptic cord blood are in harmony with the reports of others $[6,7,11,12]$.

The principal function of GPx is to protect against damage from the endogenously produced hydroxyperoxides and to catalyze the reduction of hydroxyperoxides by glutathione. Catalase promotes the conversion of hydrogen peroxide, a powerful and potentially harmful oxidizing agent, to water and molecular oxygen. It also uses $\mathrm{H}_{2} \mathrm{O}_{2}$ to oxidize toxins such as phenols, formic acid, formaldehyde and alcohols. Catalase, along-with SOD and GPx controls the levels of oxygen-derived free radicals in cells. During our present study the alteration in GPx activities was not significant $(\mathrm{p}=0.06)$ between preeclamptic maternal and cord blood. However, in control group there was $16.4 \%$ increase in GPx activity in cord blood as compared to maternal group which was significant $(p=0.011)$. There was no significant change in the activity of GRx between maternal blood and pair-matched cord blood of control and preeclamptic group ( $p=0.765$ and $p=0.863$, respectively). Interestingly, the activity of catalase was found to enhance very significantly in cord blood of normotensive and preeclamptic groups as compared to their pair-matched maternal blood $(21 \%$ and $16 \%$ increase respectively ), which show its compensatory regulation in response to increased oxidative stress. The significant elevation in preeclamptic catalase activity shows the protective effect of this enzyme, which protects the cells from the accumulation of $\mathrm{H}_{2} \mathrm{O}_{2}$ by dismutating it to form water and oxygen by using it as an oxidant in which it works as a peroxidase [26].

In conclusion, we hypothesize the elevated oxidative stress in preeclampsia, our results showed decreased SOD, GRx and GPx activities, which failed to control higher oxygen free radical produced therein, this is consistent with our previous report [3]. However, no significant decrease was found in the activities of GPx and GRx in their pair-matched cord blood. Increased activity of catalase may be a compensatory regulation in response to increased oxidative stress. Increased catalase activity in the pair-matched cord blood could be interpreted as an effort to counteract the overproduction of reactive oxygen species and provide a relief to enhanced oxidative damage in preeclampsia. From our findings of significantly low MDA contents in the pair-matched cord blood, we hypothesize that antioxidant capacity of cord blood is sufficient and placental barrier is adequate, to shield the fetus from the oxidative injury due to higher oxidative stress of preeclamptic mother. Thus, we conclude that the oxidative stress status is low in the blood of neonates compared to its level in the pair-matched preeclamptic mothers. Further studies are needed to explore strategies so that the normal levels of antioxidant vitamins are maintained to combat preeclampsia in women at high risk.

\section{Acknowledgements}

We are highly grateful to those patients of the hospital who volunteered to donate their blood when needed for this project. Our thanks are also due to the paramedical staff of the hospital for their assistance in collecting and maintaining blood samples.

\section{References}

1. Chambers JC, Fusi L, Malik IS, Haskard DO, De Swiet $\mathrm{M}$, Kooner JS. Association of maternal endothelial dysfunction with preeclampsia. JAMA 2001;285(12):16071612.

2. Wang Y, Walsh SW. Placental mitochondria as a source of oxidative stress in pre-eclampsia. Placenta 1998;19(8):581-586.

3. Suhail M, Faizul-Suhail M, Hina K. Alterations in antioxidant and pro-oxidant balance in preeclampsia. Impact on Erythrocyte Osmotic fragility. Biochemia Medica 2008;18(3):331-341.

4. Suhail M, Faizul Suhail M, Khan H. Role of vitamins C and $\mathrm{E}$ in regulating antioxidant and pro-oxidant markers in preeclampsia. J Clin Biochem Nutr 2008;43(3):210220.

5. Biri A, Bozkurt N, Turp A, Kavutcu M, Himmetoglu O, Durak I. Role of oxidative stress in intrauterine growth restriction. Gynecol Obstet Invest 2007;64(4):187-192.

6. El-Bana SM, El-Din AE, Isamil ZA. Fetal and maternal oxidative stress in normal and abnormal pregnancies. Ain Shams Med J 2001;52:421-431.

7. Orhan H, Onderoglu L, Yucel A, Sahin G. Circulating biomarkers of oxidative stress in complicated pregnancies. Arch Gynecol Obstet 2003;267(4):189-195.

8. Tastekin A, Ors R, Demircan B, Saricam Z, Ingec M, Akcay F. Oxidative stress in infants born to preeclamptic mothers. Pediatr Int 2005;47(6):658-662.

9. Karsdorp VH, Dekker GA, Bast A, van Kamp GJ, Bouman AA, van Vugt JM, van Geijn HP. Maternal and fetal plasma concentrations of endothelin, lipidhydroperoxides, glutathione peroxidase and fibronectin in relation to abnormal umbilical artery velocimetry. Eur J Obstet 
Gynecol Reprod Biol 1998;80(1):39-44.

10. Karabulut AB, Kafkasli A, Burak F, Gozukara EM. Maternal and fetal plasma adenosine deaminase, xanthine oxidase and malondialdehyde levels in pre-eclampsia. Cell Biochem Funct 2005;23(4):279-283.

11. Uotila J, Tuimala R, Pyykkö K, Ahotupa M. Pregnancyinduced hypertension is associated with changes in maternal and umbilical blood antioxidants. Gynecol Obstet Invest. 1993;36(3):153-157.

12. Jendryczko A, Tomala J. [Decreased activity of oxidoreductases in erythrocytes and blood platelets from venous and umbilical blood of women with pregnancy-induced hypertension]. Ginekol Pol 1995;66(12):656-659.

13. Jain SK, McVie R, Duett J, Herbst JJ. Erythrocyte membrane lipid peroxidation and glycosylated hemoglobin in diabetes. Diabetes 1989;38(12):1539-1543.

14. Paglia DE, Valentine WN. Studies on the quantitative and qualitative characterization of erythrocyte glutathione peroxidase. J Lab Clin Med 1967;70(1):158-169.

15. Beutler E, Red Cell Metabolism. A Manual of Biochemical Methods. 3rd, ed. Grune and Stratton Inc., New York 1984.

16. Aebi H. Catalase in vitro. Methods Enzymol 1984;105:121-126.

17. Goldberg DM, Spooner RJ. Glutathione reductase. In Bergmeyer HU ed. Methods Enzymol Basel Verlag Chemie $1983 ; 3: 258-265$.

18. Tentori L, Salvati AM. Hemoglobinometry in human blood. Methods Enzymol 1981;76:707-715.

19. Lowe DT. Nitric oxide dysfunction in the pathophysiol- ogy of preeclampsia. Nitric Oxide 2000;4(4):441-458.

20. Aydin S, Benian A, Madazli R, Uludag S, Uzun H, Kaya S. Plasma malondialdehyde, superoxide dismutase, sEselectin, fibronectin, endothelin-1 and nitric oxide levels in women with preeclampsia. Eur J Obstet Gynecol Reprod Biol 2004;113(1):21-25.

21. Niki E, Saito T, Kawakami A, Kamiya Y. Inhibition of oxidation of methyl linoleate in solution by vitamin $\mathrm{E}$ and vitamin C. J Biol Chem 1984;259(7):4177-4182.

22. Suhail M, Faizul- Suhail M. Maternal and cord blood malondialdehyde, antioxidant vitamin levels in normal and preeclamptic women. Biochemia Medica 2009;19(2):182-191.

23. Walsh SW, Wang Y. Deficient glutathione peroxidase activity in preeclampsia is associated with increased placental production of thromboxane and lipid peroxides. Am J Obstet Gynecol 1993;169(6):1456-1461.

24. Liochev SI, Fridovich I. How does superoxide dismutase protect against tumor necrosis factor: a hypothesis informed by effect of superoxide on "free" iron. Free Radic Biol Med 1997;23(4):668-671.

25. Chen X, Touyz RM, Park JB, Schiffrin EL. Antioxidant effects of vitamins $\mathrm{C}$ and $\mathrm{E}$ are associated with altered activation of vascular NADPH oxidase and superoxide dismutase in stroke-prone SHR. Hypertension 2001;38(3 Pt 2):606-611.

26. Lenzi A, Culasso F, Gandini L, Lombardo F, Dondero F. Placebo-controlled, double-blind, cross-over trial of glutathione therapy in male infertility. Hum Reprod 1993;8(10):1657-1662. 